\title{
Erratum to: A Systematic Review of Serum Biomarkers Anti-Cyclic Citrullinated Peptide and Rheumatoid Factor as Tests for Rheumatoid Arthritis
}

\author{
Peter C. Taylor, ${ }^{1}$ Juliane Gartemann, ${ }^{2}$ Jeanie Hsieh, ${ }^{2}$ and James Creeden ${ }^{2}$ \\ ${ }^{1}$ Kennedy Institute of Rheumatology, Nuffield Department of Orthopaedics, Rheumatology and Musculoskeletal Sciences, University of \\ Oxford Botnar Research Centre, Windmill Road Headington, Oxford OX3 7LD, UK \\ ${ }^{2}$ Roche Diagnostics, Ltd., Forrenstraße, 6343 Rotkreuz, Switzerland
}

Correspondence should be addressed to James Creeden, james.creeden@roche.com

Received 6 November 2011; Accepted 20 November 2011

Copyright () 2012 Peter C. Taylor et al. This is an open access article distributed under the Creative Commons Attribution License, which permits unrestricted use, distribution, and reproduction in any medium, provided the original work is properly cited.

TABLE 3: 2010 ACR/EULAR scoring criteria for RA. The following table provides the scoring criteria for different domains of evaluation. For each cell in the table for which the patient satisfies the condition, the cell is scored by the number of points at the top of the column in which it is found. The patient's score is the sum of the scores for the individual cells. Patients with a total score of 6 or more points are diagnosed as having RA.

\begin{tabular}{|c|c|c|c|c|c|}
\hline Number of points & 0 & 1 & 2 & 3 & 5 \\
\hline Joint involvement & $\begin{array}{l}1 \text { medium-large } \\
\text { joint }\end{array}$ & $\begin{array}{l}2-10 \text { medium-large } \\
\text { joints }\end{array}$ & $1-3$ small joints & 4-10 small joints & $\begin{array}{l}>10 \text { small } \\
\text { joints }\end{array}$ \\
\hline Serology & $\begin{array}{l}\text { Negative for both } \\
\text { RF and anti-CCP }\end{array}$ & & $\begin{array}{l}\text { Positive for either RF or } \\
\text { anti-CCP at low titer } \\
\text { (between } 1 x-3 x \text { upper } \\
\text { limit of normal) }\end{array}$ & $\begin{array}{l}\text { Positive for either RF or } \\
\text { anti-CCP at high titer } \\
\text { ( }>3 x \text { upper limit of } \\
\text { normal) }\end{array}$ & \\
\hline Duration of synovitis & $<6$ weeks & $\geq 6$ weeks & & & \\
\hline Acute phase reactants & $\begin{array}{l}\text { Normal CRP and } \\
\text { ESR }\end{array}$ & $\begin{array}{l}\text { Abnormal CRP or } \\
\text { ESR }\end{array}$ & & & \\
\hline
\end{tabular}

Source: [145] 


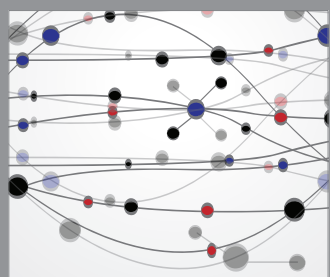

The Scientific World Journal
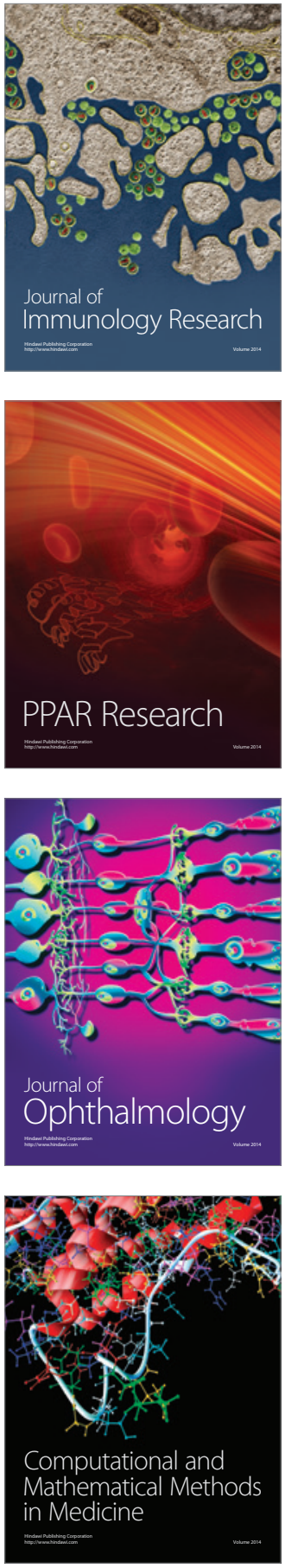

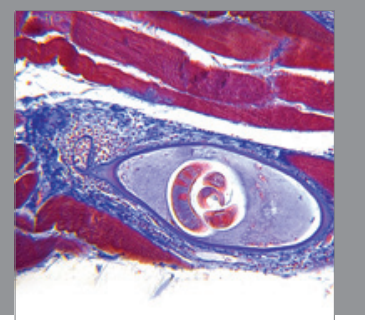

Gastroenterology

Research and Practice
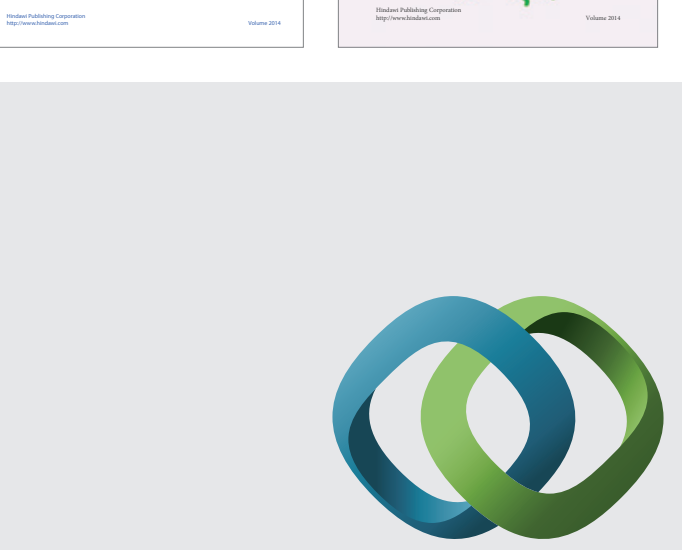

\section{Hindawi}

Submit your manuscripts at

http://www.hindawi.com
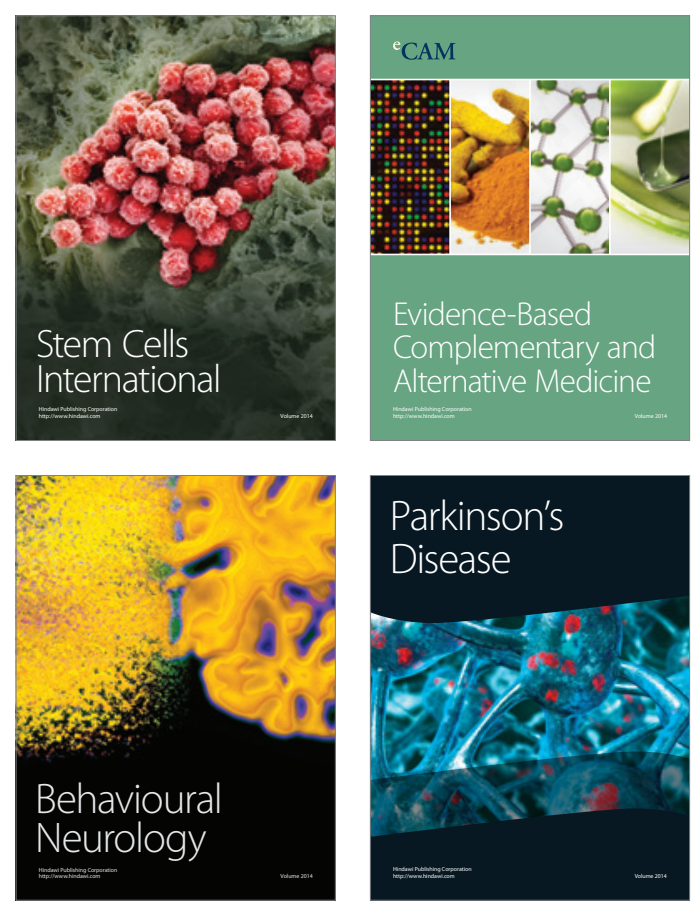

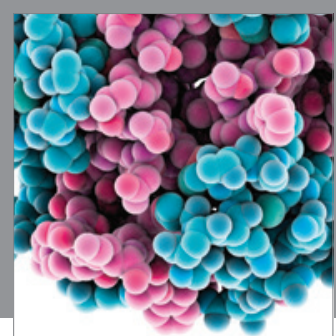

Journal of
Diabetes Research

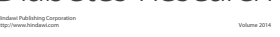

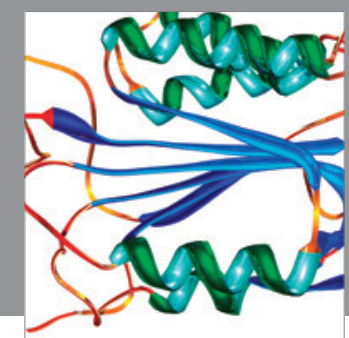

Disease Markers
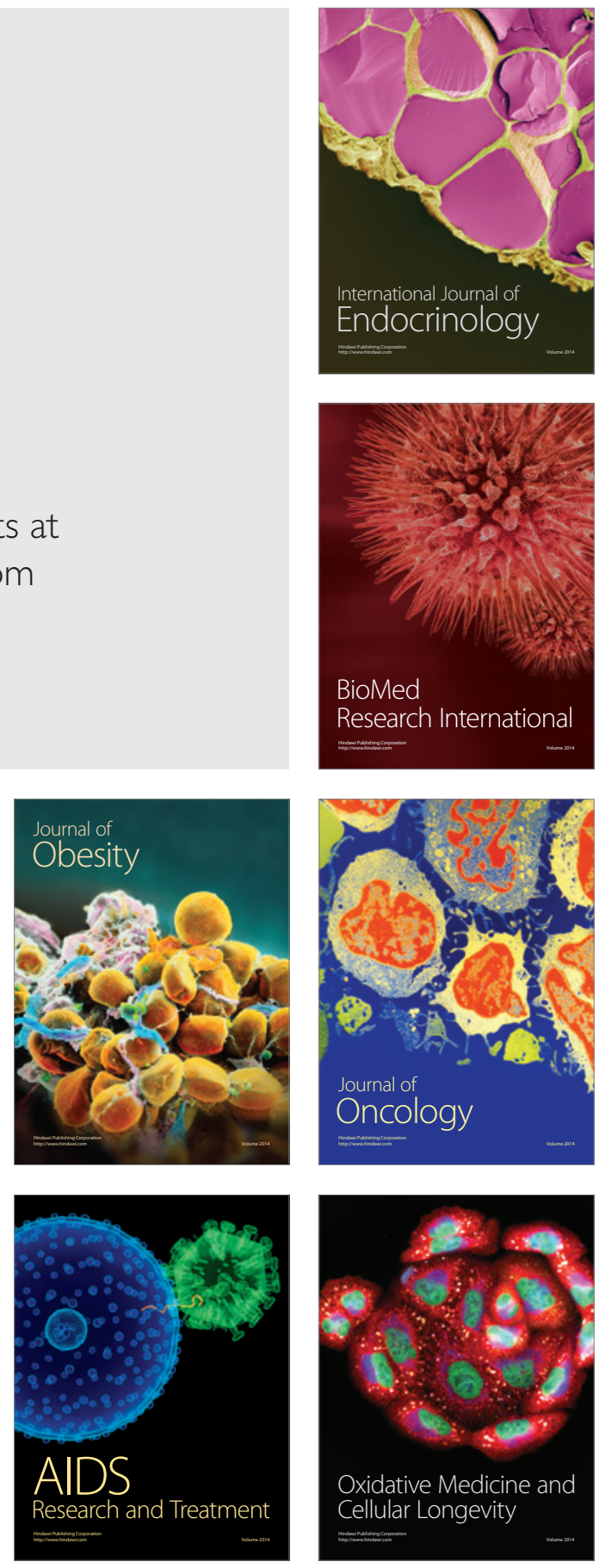